\title{
Autosomal erythropoietic protoporphyria
}

INSERM

\section{Source}

INSERM. (1999). Orphanet: an online rare disease and orphan drug data base. Autosomal erythropoietic protoporphyria. ORPHA:79278

Erythropoietic protoporphyria (EPP) is an inherited disorder of the heme metabolic pathway characterized by accumulation of protoporphyrin in blood, erythrocytes and tissues, and cutaneous manifestations of photosensitivity. 